\title{
SOME OBSERVATIONS ON THE SNOWFALL OF RUWENZORI
}

\author{
By John B. Whitrow \\ (Makerere College, University College of East Africa, Kampala, Uganda)*
}

\begin{abstract}
The seasonal precipitation of Ruwenzori is examined and the height of the climatic snowline determined. Two distinct periods of surplus accumulation and two ablation seasons can be recognized and give rise to a somewhat complex stratification. Precipitation diminishes with altitude above about ro,ooo feet $(3,050 \mathrm{~m}$.). The water equivalent of the annual accumulation on the highest peak is thought to lie between 25 and 30 inches $(635-762 \mathrm{~mm}$.). Twelve months' synoptic charts have been analysed and an attempt is made to relate the seasonal variations of accumulation and ablation to the meteorological factors accompanying the oscillations of the Inter-Tropical Convergence Zone.
\end{abstract}

RÉsumé. L'auteur expose l'étude des précipitations saisonnières au Glacier de Ruwenzori et détermine l'altitude de la limite climatique des neiges. Il est possible de reconnaître deux périodes bien marquées d'accumulation nette et deux saisons d'ablation, ce qui donne naissance à une stratification quelque peu compliquée. Les précipitations diminuent avec l'altitude au-dessus de $3050 \mathrm{~m}$. La valeur en eau de l'accumulation annuelle sur le sommet le plus élevé semble osciller entre 635 et $762 \mathrm{~mm}$. L'analyse des cartes synoptiques couvrant une période de douze mois a permis de faire un essai pour trouver une relation entre les variations saisonnières de l'accumulation et de l'ablation et les facteurs météorologiques provoqués par les oscillations de la zone de convergence inter-tropicale.

Zusammenfassung. Der jährliche Niederschlag in Ruwenzori wird untersucht und die Höhe der klimatischen Schneelinie bestimmt. Zwei deutliche Abschnitte überschüssiger Akkumulation und zwei Ablationsstufen können festgestellt werden und geben Anlass zu einer etwas komplexen Schichtung. Der Niederschlag nimmt bei einer Höhe über ungefähr $3050 \mathrm{~m}$ ab. Es wird angenommen, dass die auf der höchsten Kuppe der jährlichen Akkumulation äquivalente Wassermenge zwischen $635-762 \mathrm{~mm}$ liegt. Synoptische Karten wurden über eine Periode von 12 Monaten ausgewertet, und es wird der Versuch gemacht, jahreszeitliche Änderungen mit Akkumulation in Beziehung zu bringen und Ablation mit den meteorologischen Faktoren, die die Oszillationen der intertropischen Konvergenzzone begleiten.

IT HAs long been recognized that consistent with its position on the equator Ruwenzori exhibits a characteristic double maximum of precipitation annually, between which occur the so-called "dry" seasons. The latter are not truly dry but merely mark the precipitation minima. Calculations by Makerere College expeditions suggest that the climatic snow line on the eastern side of Ruwenzori may be as low as $14,700 \mathrm{ft}$. (4,480 m.), (compared with the figure of ${ }_{1} 5,580 \mathrm{ft}$. $\left(4,75^{\circ} \mathrm{m}\right.$.) for the western slopes), although Bergström ${ }^{\mathrm{I}}$ calculated that in 1952 the firn line on the eastern slopes stood at a height of ${ }_{15}, 000 \mathrm{ft}$. $(4,573 \mathrm{~m}$.). Thus the climatic snow line (firn line) on the Elena Glacier probably stands at an elevation midway between these two figures, and above this point attempts have been made to study the annual and seasonal fluctuations of precipitation.

It is generally agreed that during the two wet seasons of March-May and SeptemberDecember there is usually a surplus accumulation of snow above $\mathrm{i} 5,000 \mathrm{ft}$. $(4,570 \mathrm{~m}$. $)$ resulting not only from the increased precipitation during these months but also from the decrease in ablation owing to the greater cloud cover. It has also been recognized that during the so-called "dry" seasons of January-February and June-August the smaller snowfall and the decreased cloud cover have resulted in the ablation being greater than the accumulation. These seasonal variations have manifested themselves in a stratification of the firn. The wet seasons are represented by the layers of firn which exhibit varying degrees of consolidation, whilst at fairly regular intervals dirt bands have previously been thought to be indicative of the more prolonged melting of the "dry" seasons. It is demonstrated below, however, that the thickness of the dirt band does not necessarily depend on the ablation rate. A dirt band will only form when aeolian material is available, so that in some cases melting may be intense and yet not be associated with a dirt band. It is believed that the dirt bands are coloured by dust and ash, the former being deposited on the glaciers by airstreams

* Present address: Department of Geography, University of California, Los Angeles, U.S.A. 
blowing from the arid lands of Egypt, the Sudan and Arabia at this season, and the latter resulting from the burning of the grasslands at lower altitudes. This characteristic feature of the native economy, although carried out in both "dry" seasons, is more pronounced in the January-February period, especially in north-west and north Uganda, so that the northerly airstreams carry the ash southwards to Ruwenzori. Thus it is probable that in most examples the January-February dirt band is better developed than that marking the June-August precipitation minimum. Indeed, in some cases the latter may not be clearly defined by a dirt layer, only by a marked change in the character and the density of the firn. Of the three pits dug in the firn area by the fourth Makerere College expedition in June I959 only one

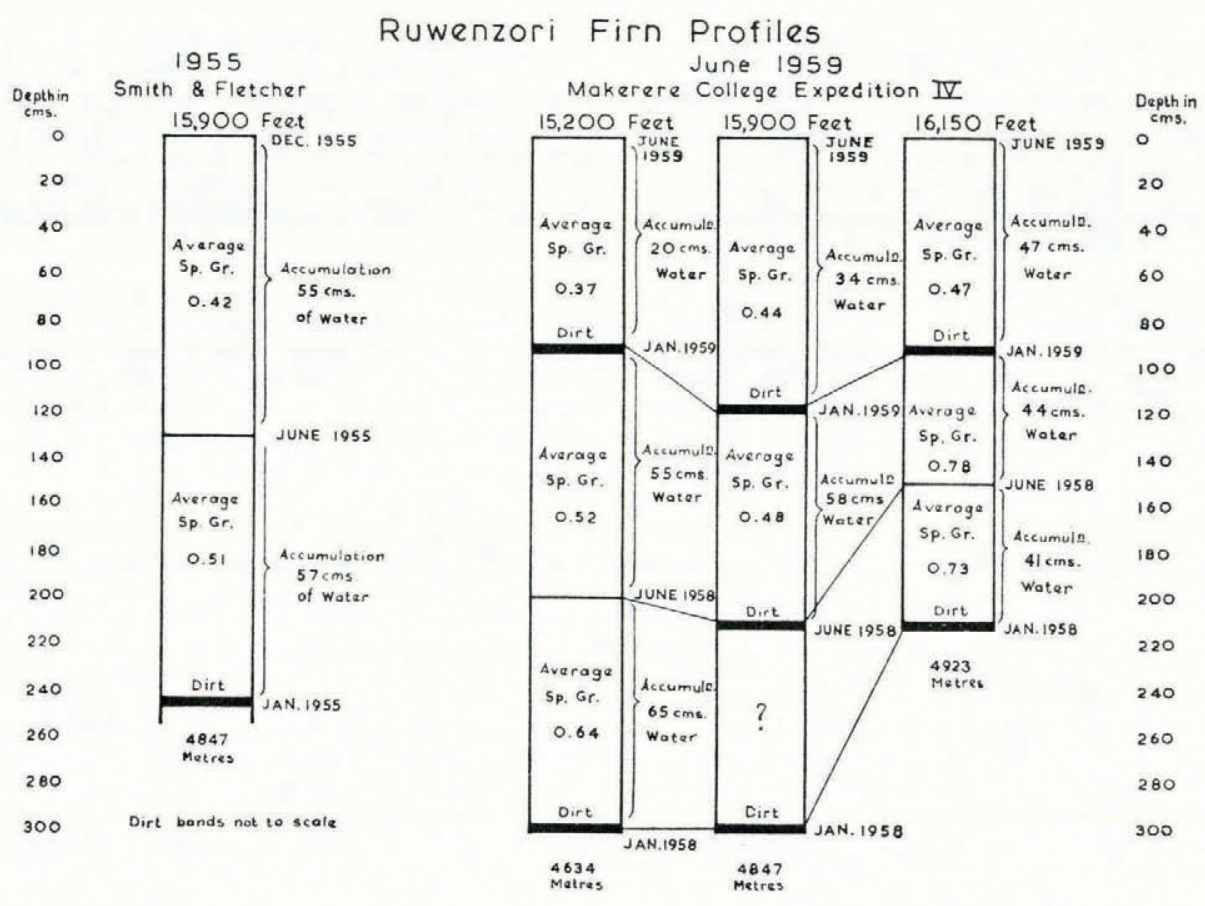

Fig. $I$

pit exhibited a dirt band to mark the June ablation period, whilst in every case the January dirt bands were clearly marked (Fig. I). The work of Smith and Fletcher on the Elena Glacier in 1955 also pointed to the same probability, ${ }^{2}$ so that the conclusions reached by Bergström, that the thicker dirt bands are formed in June and July, may have to be revised. A further complication in the stratification is caused by periods of melting which may occur at any time of the year during a spell of decreased cloudiness, and which may result in a thin dirt band being formed if the synoptic situation is favourable.

The first set of measurements in the Ruwenzori firn was made by Bergström who visited the Elena Glacier during June and July 1952. He concluded that surplus accumulation increased to an altitude of $15,250 \mathrm{ft}$. (4,650 m.), above which it decreased at higher altitudes. $\mathrm{He}$ attributed this to an increase of ablation above $15,250 \mathrm{ft}$. $(4,650 \mathrm{~m}$.).

Another set of figures, also from the Elena Glacier, was provided by Menzies 3 in I 953 , and his conclusions pointed to an increase of surplus accumulation with altitude. Here then 
were two diametrically opposed views concerning the accumulation/ablation balance of the Elena Glacier, so that no definite conclusion could be reached without a further investigation.

Prior to I 957 measurements of accumulation had all been made at heights between I5,00o ft. (4,570 m.) and I 5,580 ft. (4,750 m.), so that when the Makerere College expeditions visited the Elena Glacier at six-monthly intervals between 1957 and 1959 in connection with the International Geophysical Year it was thought necessary to obtain results at higher altitudes. Consequently pits were dug at heights of $\mathrm{i}_{5}, 200 \mathrm{ft}$. $(4,634 \mathrm{~m}$.), I5,900 ft. (4,847 m.), and I6, I50 ft. $(4,923 \mathrm{~m}$.), the last being sited just below the highest peak (Margherita Peak, I $6,763 \mathrm{ft}$. (5, I I I m.)) (Fig. I). The recorded measurements suggest that the surplus accumulation for the budget year January-December $195^{8}$ showed a tendency to decrease with altitude. The water equivalent of the surplus accumulation exhibited a decline from 48 in. ( 1,2 I $9 \mathrm{~mm}$.) at $\mathrm{I} 5,200 \mathrm{ft}$. $(4,634 \mathrm{~m}$.) to $34 \mathrm{in}$. (863 mm.) at $\mathrm{I} 6, \mathrm{I} 50 \mathrm{ft}$. $(4,923 \mathrm{~m}$.), so that by extrapolation the surplus accumulation on the highest Ruwenzori peak may be equivalent to $25-30$ in. $\left(635-762 \mathrm{~mm}\right.$.) of water for the year of i $95^{8}$. $^{*}$ It is emphasized that the figures apply to surplus accumulation only, i.e. accumulation which remains after radiation melting and any other loss by evaporation or removal by wind. Unfortunately, so far as is known, no records of evaporation in the glacier zone of Ruwenzori are in existence, but the high relative humidity which has been recorded even in the "dry" seasons suggests that evaporation may not be very great, and the lack of penitentes on the snow surface may also be significant in this respect. It is probably true, that apart from evaporation, other meteorological factors are of small importance to the ablation, so that actual precipitation on the highest summits may very well be only slightly greater than the figures quoted above. A point worthy of future investigation is the part played by rime in the accumulation on the Ruwenzori summits. Although this type of accumulation may be small, there appears to be a certain amount of impacting of droplets against the high ice summits, probably during the night.

Thus the Makerere College observations on the whole agree with Bergström's findings, that on the high peaks surplus accumulation of snow decreases with altitude and that this can probably be attributed to the ablation which appears to increase with altitude above a critical height. The considerable number of ice bands and the coarse nature of the firn at the highest of the I959 pits were such as to suggest considerable melting and re-freezing at the surface. The firn density at this elevation was therefore remarkably high, and may be further proof that the greatest rate of ablation can probably be found on the highest peak of Ruwenzori. Since it has been demonstrated how the converse is true in high latitudes 4 it is important to attempt an explanation for this phenomenon. A further outstanding problem is to discover why the ablation rate is significantly greater during the June-August "dry" season than during the January-February "dry" season, a fact which was recorded in 1958 and again in 1959. The answer to both problems is almost certainly connected with the fluctuations in the amount of insolation which reaches the high summits and therefore with changes in the cloud cover. Is it possible, for example, that the highest peaks project periodically into a zone of drier and less cloudy air? In order to examine this possibility it is necessary to analyse the nature of the various air masses which affect Ruwenzori.

In recent years the East Africa Meteorological Department have been able to construct detailed synoptic charts of tropical Africa as an aid to air navigation, and through their kind co-operation it has been possible to examine these charts in an attempt to account for the seasonal variations of accumulation and ablation on Ruwenzori. It is well known that as a result of differential heating the large East African lakes and the vast areas of swamp play an important rôle in the determination of the local wind directions. Thus a study of the surface wind directions at the stations surrounding Ruwenzori would tend to give a false impression of the overall air movement in the region. Instead the contours and streamlines, which ignore

* It is noteworthy that an isolated figure of $1,120 \mathrm{~mm}$. which was obtained above the Elena Glacier at a height of $4,847 \mathrm{~m}$. for the year of 1955 , accords well with the Makerere figures; see ref. 2. 
the local peculiarities, give a much clearer indication of the slowly changing pressure patterns and airstreams of tropical Africa. A twelve months' series (September I958-August I959) of these synoptic charts has been analysed, and it has usually been possible by following the streamlines to establish the source regions of the air masses which affect Ruwenzori from day to day. Since the charts showed airstream directions at selected heights between $5,000 \mathrm{ft}$. $(1,524 \mathrm{~m}$.) and $24,000 \mathrm{ft}$. $(7,317 \mathrm{~m}$.) it soon became evident that the directions of air movement differ considerably at different altitudes around Ruwenzori. Further examination showed that as the Inter-Tropical Convergence Zone fluctuated seasonally so the air masses affecting Ruwenzori were constantly changing. It eventually became possible to distinguish five air masses which affect the Ruwenzori region at different times of the year. The source regions from which these air masses originate are as follows (Fig. 2):
I. South Atlantic-Congo
II. Indian Ocean
III. Southern Africa
IV. South-west Asia
V. Sahara-Sudan

It will be recognized that air masses originating from either the Atlantic or Indian Ocean high pressure systems can generally be considered as moisture laden, whilst those beginning their journeys in south-west Asia or the Sahara-Sudan zone are normally predominantly dry. Nevertheless, it must be remembered that the character of the individual air mass depends on the track which it follows before reaching the Ruwenzori region. A study of weather conditions associated with the Indian Ocean and the Atlantic-Congo air masses makes it possible to include them in the broad category "predominantly moist", for it is during the time that Ruwenzori is primarily under their influence that the greater portion of its precipitation is recorded.

On turning to the other broad category which includes the "predominantly dry" air masses it is found that the air coming directly from the desiccated lands of Egypt, the Sudan and Arabia is undoubtedly associated with dry weather conditions, punctuated only occasionally by thunderstorms. Although these northerly and north-easterly airstreams are often in evidence at high altitudes even during the rainy seasons, they are most pronounced during January and February, the months during which precipitation on Ruwenzori is at its minimum.

The most difficult of the air masses to place in either of the categories is that which originates over the high plateaux of southern Africa, usually during the southern winter. Although on some occasions the air must pick up a considerable amount of moisture during its passage through the Mozambique Channel on its way equatorwards, in the majority of cases the track is directly northwards through the fairly dry interior of the Rhodesias and Tanganyika. Consequently, when plotting the individual air masses, that from southern Africa was placed in either the "predominantly moist" or "predominantly dry" category according to whether its track was primarily a marine or an overland one.

Having decided whether a particular air mass is "predominantly moist" or "predominantly dry", it becomes possible to suggest the variations in moisture content which may have existed simultaneously at varying altitudes around Ruwenzori in each month during the period under observation. The results were plotted in terms of percentage frequencies against altitude on monthly graphs which when compared showed significant seasonal changes.

The first graphs to be plotted were those covering the rainy season of September-December 1958. During this season the Inter-Tropical Convergence Zone is moving southwards and Ruwenzori is strongly influenced by moisture-laden air masses from the South AtlanticCongo and the Indian Ocean. Airstreams from the former are particularly prevalent in Western Uganda at this time, and it appears that, in contrast to the rest of Uganda where the 
"long rains" occur in the March-May season, Western Uganda receives its most prolonged precipitation during the period September-December. Figure 3 (p. 770), which depicts the there is no dry zone at anyses which affected Ruwenzori in November 1958, suggests that through the water-logged forests andion on the mountain. The approaches to the glaciers, zori at this time, but a solitary clims, are so difficult that few people venture on Ruwencover, heavy rainfall, and a climber in November $195^{8}$ reported almost continuous cloud cover, heavy rainfall, and a thick accumulation of fresh snow in the glacier zone. With little

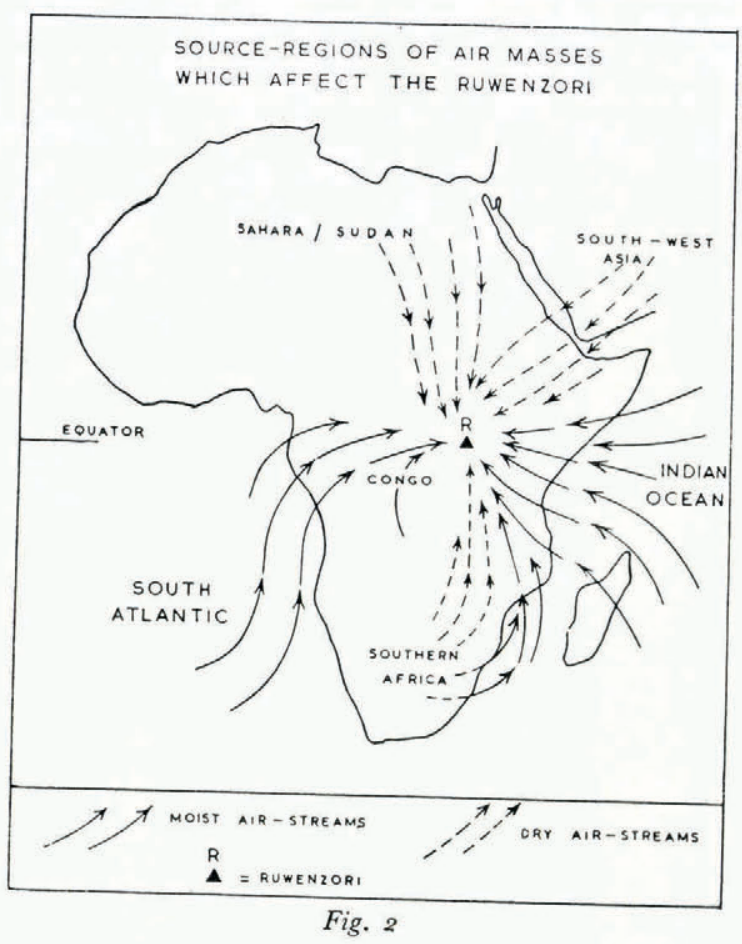

direct insolation reaching the glaciers one would expect ablation to be very low, and the short-term measurements of the run-off from the Speke Glacier in November 1958 show that
the mean daily ablation rate was only $0 \cdot 06$ cusecs.

By January 1959, when the Inter-Tropical Convergence Zone had moved far to the south and Ruwenzori was under the influence of "predominantly dry" air masses mainly from North Africa, the third Makerere College expedition was on the mountain. It was found that weather conditions were exceptionally dry, particularly on the lower slopes. Figure 4 (p. 770) shows the graph for January 1959, and it is clear that "predominantly dry", airstreams exceed the "predominantly moist" airstreams at all elevations on Ruwenzori up to $16,500 \mathrm{ft}$. $(5,030 \mathrm{~m}$.). Above this altitude the graph suggests that at higher levels there occurred periodic convergence of moist airstreams which may have caused occasional cloud patches around the highest summits. It must be remembered, however, that quite small clouds would result from the local effects of heating above the moist glaciers. Although ablation was found to exceed accumulation during this month, the mean daily melt rate from the Speke Glacier of 0.23 cusecs. showed that it was not as high as had been anticipated. The February graph (Fig. 5, p. 77I) suggests that relatively dry conditions still existed up to a height of $\mathrm{I} 4,700 \mathrm{ft}$. $(4,48 \mathrm{om}$.), although convergent moist airstreams appear by now to 
be in the ascendant on the highest peaks. The significance of the pattern in Figures 4 and 5 may be that, although the low-level stations surrounding Ruwenzori are recording only scanty rainfall during the pronounced "dry" season of January-February, it is probable that the summits are periodically cloud covered and the ablation rate reduced as a result of the high-level convergent airstreams noted above. If, however, very little moisture-laden air is rising orographically or convectionally from the surrounding lowlands it is unlikely that there will be significant precipitation anywhere on the mountain. A contributory factor to the lowered ablation rate must be the dust haze of this season, since it is common for convection to continue to above $40,000 \mathrm{ft}$. (12,195 m.) during a northerly airstream.

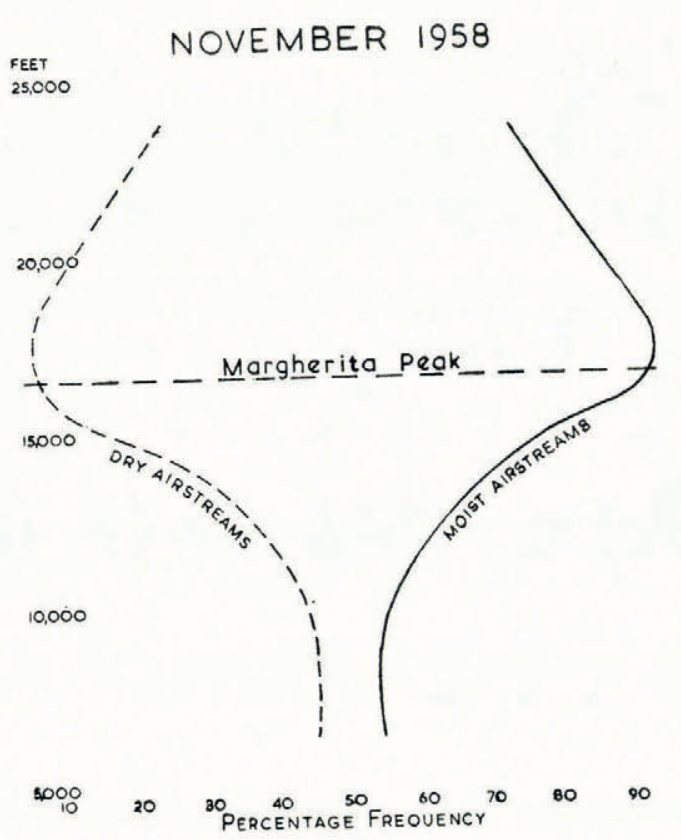

Fig. 3

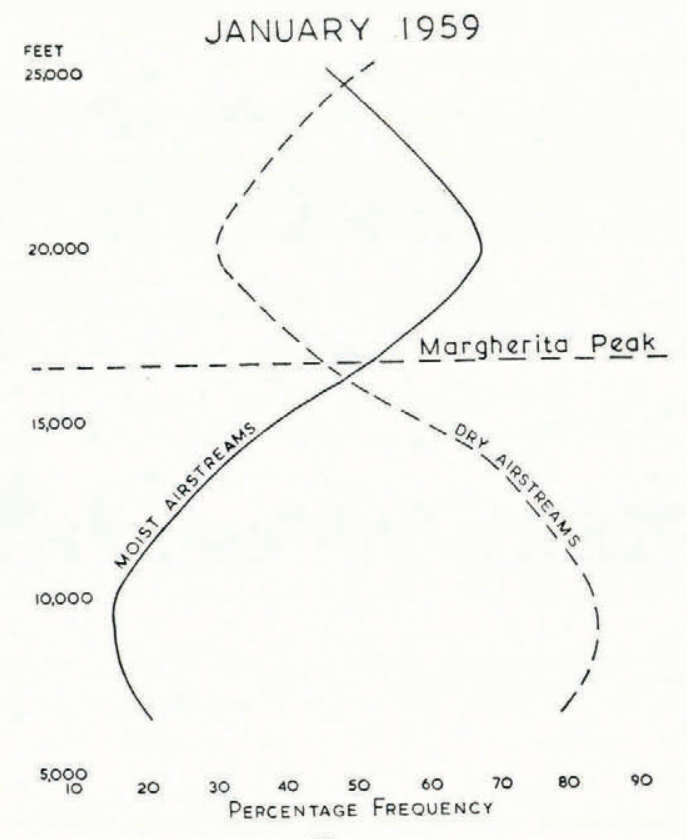

Fig. 4

By April another rainy season has usually begun in Western Uganda after the passage of the Inter-Tropical Convergence Zone on its way northwards, and Figure 6 exemplifies typical conditions which might be expected on Ruwenzori. Moisture-laden air masses from the South Atlantic-Congo and the Indian Ocean are again dominant, meeting in a north-south trending convergence zone, and it is probable that precipitation is heavy at all altitudes. No ablation figures are available from this season, but they would probably be similar to those recorded in November $195^{8 .}$

The month of June usually marks the end of the rainy season in Western Uganda, although in fact May was a remarkably dry month in 1959. Figures 7 and 8 illustrate how in June and July conditions are entirely reversed from those of January. The "predominantly moist" airstreams appear to be affecting the lower slopes of Ruwenzori up to an altitude of about $12,000 \mathrm{ft}$. $\left(3,65^{8} \mathrm{~m}\right.$.), whilst above this height it appears from the graph that the higher peaks are projecting into a zone of relatively drier air.* A study of the contour charts suggests that whilst at lower altitudes periodic convergence occurs between Congo and

* This phenomenon was noted in June and July 1952, when the summits above 14 , $100 \mathrm{ft}$. $(4,300 \mathrm{~m}$.) were frequently above the cloud layer; see ref. 1, p. 476 . 


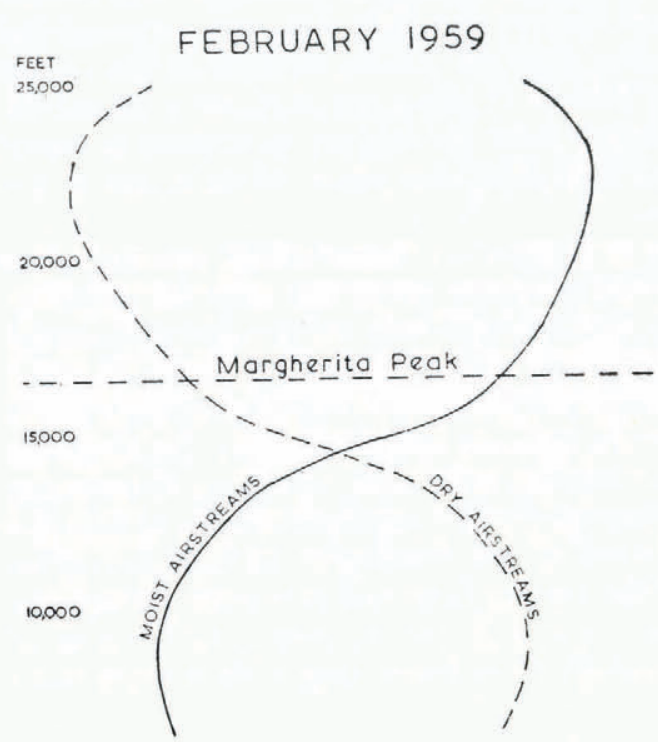

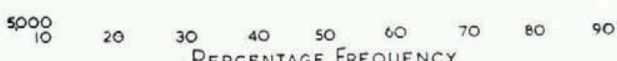
Fig. 5

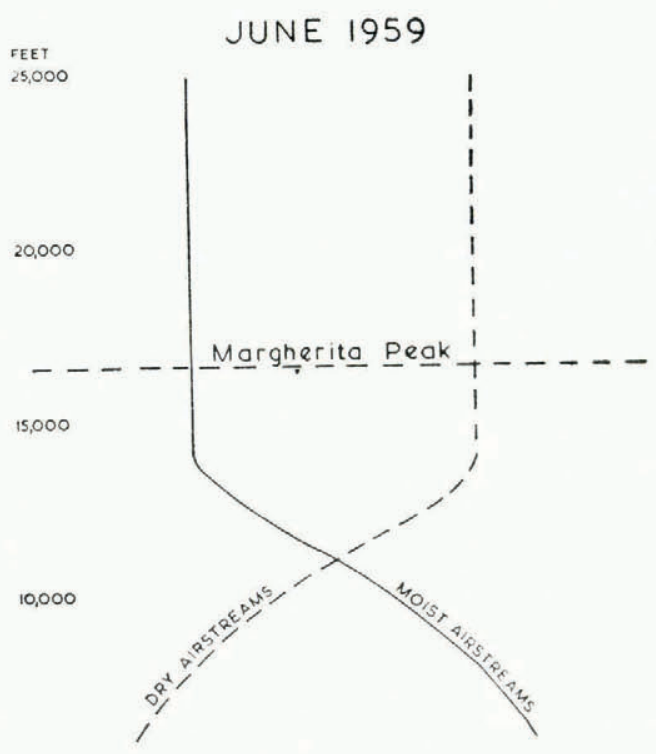

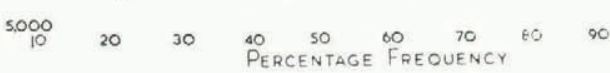

Fig. 7

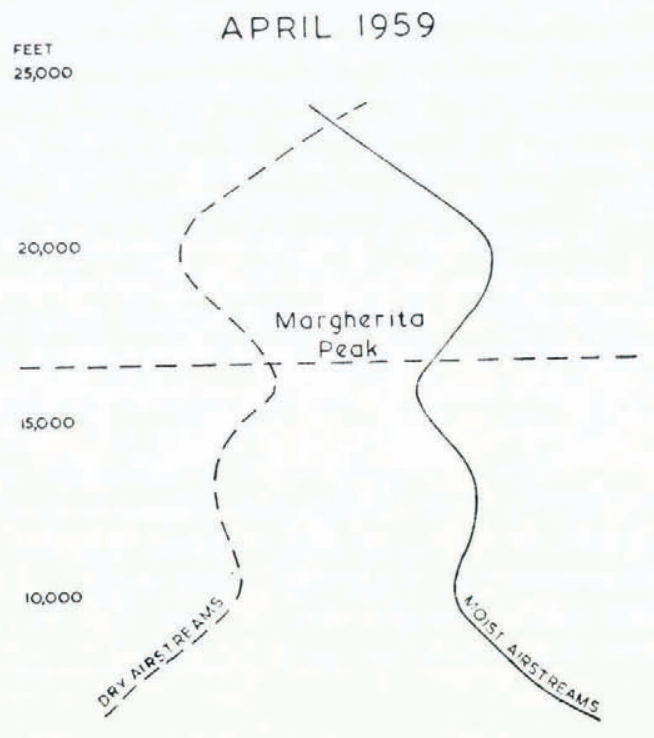

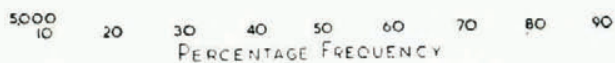

Fig. 6

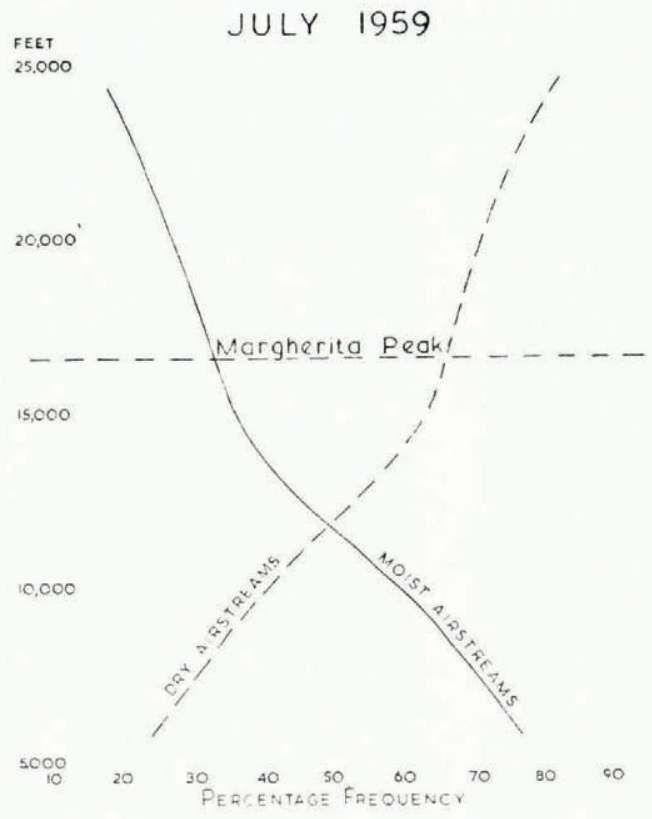

Fig. 8 
Indian Ocean air, there is no evidence of convergence at higher altitudes. The fourth Makerere College expedition was on the mountain in June and July r 959, and although the summits were often seen to be cloud-free for lengthy spells the parties working in the valleys and on the glaciers, at lower elevations ( $13,000-\mathrm{I}_{5}, 000 \mathrm{ft}$. $(3,963-4,573 \mathrm{~m}$.)), were frequently hampered by cloud rising up the slopes, presumably from the moister airstreams at lower elevations. Owing to the general absence of high-level cloud the mean ablation rate of the Speke Glacier was recorded as being 0.67 cusecs.*

In conclusion it may be said that the method of plotting air masses which was described above suggests a possible explanation of some of the problems concerned with the ablation/ accumulation balance on Ruwenzori. It has been demonstrated how the possible existence of moist airstreams at high altitudes in January and February may cause cloud formation around the highest summits and this may in turn account for the decreased ablation compared with the June-July figures. In addition it is fairly certain that the dust haze from the northerly and north-easterly airstreams of this season would interfere with solar radiation. Because the January-February season was known to be the drier of the two on the lowlands of Western Uganda it was originally thought that the ablation on the Ruwenzori glaciers would be correspondingly high. The graph suggests, however, that in June and July even though the mountain slopes are often obscured by cloud, the summits frequently project into a zone of drier and clearer air, so that ablation is approximately three times greater than in January
and February.

\section{Acknowledgement}

The author is indebted to all members of the Makerere College expeditions for their assistance in the collection of many of the data contained in the above paper.

The Makerere College Ruwenzori I.G.Y. expeditions were aided by generous grants from the Royal Society, the Mount Everest Foundation, the Royal Geographical Society, and the Makerere College Research Grants Board. The glaciological studies represent a continuation of work initiated in association with the Royal Society's British National Committee for the International Geophysical Year.

MS. received 20 April 1960

\section{REFERENCES} 1. Bergström, E. British Ruwenzori Expedition, 1952: glaciological observations-preliminary report. Journal of
Glaciology, Vol. 2, No. 17, 1955, p. 469-76.

2. Smith, J., and Fletcher, T. E. [Unpublished.]

3. Bergström, E. op. cit., p. 474 .

4. Ahlmann, H. W. Glaciological research on the North .Allantic coasts. London, Royal Geographical Society, $194^{8 .}$ 5. Information from N. Downham of the Kenya Police.

* This can be compared with the mean figure of 0.64 cusecs. recorded in June I $95^{8}$ (second Makerere
Tlege expedition). 